http://dx.doi.org/10.4314/gjl.v8i1.3

\title{
FRAMING AND PERSPECTIVES: EXPLORING THE RHETORICAL FUNCTIONS OF THEMATIC CHOICES IN NIGERIAN EDITORIALS ON TERRORISM IN NIGERIA
}

\author{
Bukola Alfred \\ Rotimi Taiwo
}

\begin{abstract}
This paper explores Nigerian media's choices of Themes in editorials on terrorism in Nigeria. The study relates to how well Nigerian newspaper organisations attempted to reveal or mask security cases across different regions of the country through thematic choices. The editorials were sourced from The Punch and The Guardian (South-Western region), Vanguard and The Sun (East Region) and Leadership and Daily Trust (Northern Region) between 2014 and 2016. Our findings show that preposition-headed adjuncts occurred the most in thematic positions. Marked adjuncts were used to substantiate claims, inject prejudices and mark varying degrees of commitments. Marked complements were thematised to project the sufferers/victims of violence, thus achieve emotive effects on the readers. The multiple Themes were made to function as adversatives, correctives, emphases and stance markers on security measures in the editorials. All the newspapers employed thematic relations that explicitly projected negative disposition to the violent activities of cattle herders, Boko Haram insurgents and Niger Delta militant in Nigeria.
\end{abstract}

Keywords: Theme, Nigerian Newspapers, Framing, Editorials, Terrorism

\section{Introduction}

Human beings employ most of their time communicating in one way or the other, on daily basis, either through verbal, non-verbal or written means. According to Owolabi (2016:242), "language does not exist...because man is a rational being; it exists because man is a sociable creature". Ekeanyanwu \& Jokodola (2009) says that man is born with an innate desire to always communicate with other people. On a daily basis, individuals seek to persuade and convince people in order to get things done. All these intentions are made possible through communication. The interpretation of any 
message depends, to a large extent, on the way such is packaged. The skilful use of language encompasses an individual's ability to use language in achieving intended results in specific situations. Halliday \& Mathiessen (2004) opine that the choices of certain lexical choices and syntactic patterns have functional roles in relating the writer's or speaker's intentions to an audience. Thus, it could be said that there is a nexus between the preferences for syntactic constructions and intentions of a language user. This paper analyses the way news organisations in Nigeria frame their comments on terrorism in Nigeria.

It is often said that one out of every five black men would likely be a Nigerian (AjodoAdebanjoko \& Okorie, 2014:11). Nigeria is currently battling with different security challenges such as Boko Haram insurgency, Herdsmen attacks and Niger-Delta militancy. The several strategies put up by the government over the years to curb terrorist attacks have simply resulted in superficial window dressing as there has not been any noticeable improvement on the security state of the nation. The severe havoc wrecked by these menaces have prompted Nigerian newspaper organisations to express their dispositions towards these security issues. What necessitated this research is the need to examine how Nigerian newspapers employ the textual metafunction in relating security issues and marking ideological assumptions to certain segments of editorials on terrorism in Nigeria.

\section{A Brief History on the Emergence of Terrorism in Nigeria}

There have been several arguments as to what constitutes terrorism in different disciplines. Such arguments have generated from criminologists, security personnel and legal experts. This study adopts Pinkerton Global Intelligence Service (PGIS) description of terrorism as actions involving the threatened or actual use of unlawful coercion and violence to achieve certain goals (Lafrue \& Dugan, 2007). Several scholars have written on the history of terrorism in Nigeria as well as the perceived motives and motivations of different terrorist groups in Nigeria. Chinwokwu (2012) attribute the genesis of this menace to the forceful amalgamation of unwilling ethnic groups in Nigeria, which resulted in feelings of religious and political rancour, perceived oppression, marginalisation of the minority groups and undue favouritism of majority groups. These feelings have snowballed into more grave security threats and attracted global concerns.

For instance, on 1st October 2010, a home-grown terrorist bomb attack was hatched in the Federal capital Territory (Abuja) by a group known as the Movement for the Emancipation of the Niger Delta (MEND), in the south-south region of Nigeria, during the country's golden jubilee anniversary. This was preceded and followed by several other bomb attacks and kidnappings in different states of Northern Nigeria by an Islamic sect, Boko Haram. Terrorism in Nigeria took a new turn after the April 2011 
general elections. The Police Headquarters, Abuja was bombed on June 16, 2011; United Nations Office, Abuja was also bombed on August 26, 2011. Schools and places of worships have also been under bomb attacks by the Boko Haram sect. Cattle herders also launch attacks on villages in rural communities in different parts of the country. Villagers/ farmers are massacred at will by these nomadic herdsmen when accesses to farmlands are denied the grazing cattle. The insecurity state of the country has earned the nation international stigmatisation and Nigeria is being blacklisted as a terror nation by the US government (Dankano, 2010; Ojeme, 2011). Terrorism in the country has thus been heightened in Nigeria by religious differences, ethnic marginalization and agricultural factors.

\section{Thematisation in Texts}

Halliday (1994) establishes that every clause has a Theme-Rheme structure, one part starting the message, the other completing it. The Theme is usually a linguistic item employed at the initial position within a clause structure, in preparation for the message which is contained in the rheme. Every clause has a message that is expressed according to the order of syntactic arrangement. Bloor and Bloor (1995:72) define the Theme as that "constituent at the starting point of a clause" that a communicator initiates his message with. The authors compare thematic structure to information structure and observe that the Theme is usually parallel to "given information" while the rheme represents "new information" (p.72). Taiwo (2001) adds that the Theme reveals the perspective from which the writer or speaker intends to communicate the message. Fries (1995:12) refers to the Theme as the "orienter" of the communicator's message. In the author's view, it is meant that the function of the Theme is to direct or guide the audience to the message which is contained in other parts of the clauses other than the first element. Downing and Locke (2006:224) state that the Theme represents a speaker or writer's choice of clausal initial element whether in a bid to link the present clause with earlier ones or deter the message of the clause till later. The Theme is "the element which serves as the point of departure of the message" (Halliday \& Mathiessen, 2004: 64; 2014: 89). The remaining part of the message in which the Theme is developed is called the rheme. There have been arguments as to what elements could be said to function as Theme. Huddleston (1988) is of the opinion that the Theme could be any element occupying any position within a clause structure as long as it conveys an important sense. The author adds that thematised elements must have semantic contents. Osisanwo (2001) also brings to play the issue of intention on what is thematised.

Thematic analysis is carried out against the backdrop that what occupies the initial position in a clause is significant and has a way of influencing the perception of readers. An unmarked Theme usually has an agent/ actor conflating with the subject, while a marked one would have a verb, complement or adjunct at the initial position based on the communicator's choice. In textual meaning, Halliday and Mathiessen 
(2014:79) opine that the unmarked Theme conflates with the "psychological subject", "logical subject" and "grammatical subject" while the marked Theme is "something other than the Subject, in a declarative clause" (p.98). Other experiential elements that could occur at the initial position are adverbials, complements and verbs. A simple Theme "contains one, and only one, of these experiential elements" (p.105) while a multiple Theme combines two or at most three of the experiential elements.

\section{Linguistic Studies on Terrorism Discourse in Nigeria}

Terrorism Discourse in Nigeria has enjoyed great attention from linguists who have tried to investigate how Nigerian print media construct the activities of certain terrorist groups. Ayoola (2010) examined the Nigerian newspapers' ideological perspectives on Niger-Delta activities from the critical discourse approach. Igwebuike and Taiwo (2015) examined the representation of the Bakassi-Peninsula Conflict in Nigeria and Cameroon print media, through the system of transitivity. Osisanwo (2016) explored the discourse strategies deployed in Nigerian news reports on the representation of Boko Haram terrorism. Although, these works serve as a springboard from which this research work takes off, they have not considered the media's uses of clausal framing and thematisation in representing terrorist attacks in Nigerian newspaper editorials. The objectives of the study are to (a) identify and analyse the thematic choices in the editorials and (b) discuss the semantic and discourse implications that these choices have on the ideological projection of certain segments of the editorials.

\section{Methodology}

The corpus for this study comprises editorial from six Nigerian dallies namely The Guardian, The Punch, The Vanguard, The Sun, Leadership and Daily Trust. The newspapers are selected from the different ethnic divisions in Nigeria and ethnicity may influence the different new organisations' perception of, and framing of certain social participants in the security incidents. The editorials were those published between 2014 and 2016 - a period when the security issues were quite intense. The study is hinged on Halliday's (2014) Systemic Functional Linguistics (SFL)

\section{Findings and Discussion}

The analysis of Themes in the selected editorials was done from the perspectives of simple/multiple Themes. The frequencies and percentages of the marked/unmarked Themes in the simple thematic structure as well as the frequencies of multiple Themes were examined. An attempt was made at investigating what clausal elements 
characterise the thematic positions and what semantic and ideological implications such thematic projections have on editorials of this nature. An attempt was also made to see how well the thematic structures adopted by the newspapers objectively relate security problems in the different regions of the country.

From the analysis, it was discovered that the simple Theme was mostly employed in news editorials on security challenges. While the simple Theme appeared 1397 times, the multiple Theme appeared only 193 times in the entire data. Out of a total of 1397 occurrences of the simple Theme, 1085 were unmarked, having a percentage of $77.7 \%$, while just 312 were marked constituting about $22.3 \%$ of the total occurrences of simple Themes. In the multiple thematic structure, out of a total of 193 multiple Themes, conjunctive adjunct + ideational Theme had the highest occurrence, appearing 81 times with a percentage of $42 \%$ and this was followed by modal adjunct + ideational Theme, appearing 54 times with a percentage of $28 \%$. Conjunction + ideational Theme occurred 40 times with a percentage of $20.7 \%$ while continuative + ideational Theme appeared 18 times, having a percentage of $9.3 \%$. This interpretation is shown in the table below.

Table 1: Frequency of Occurrences of the Theme System as Used across all the Editorials

\begin{tabular}{|c|c|c|c|c|c|c|c|c|c|c|c|c|c|}
\hline \multicolumn{2}{|c|}{ Theme Type } & \multicolumn{2}{|c|}{ 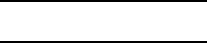 } & & LEs & VEs & GEs & PES & SEs & DTES & \multicolumn{2}{|c|}{ Total } & $\%$ \\
\hline \multirow{6}{*}{ Simple } & \multirow{6}{*}{ Marked } & \multirow{3}{*}{\multicolumn{2}{|c|}{ Adjunct }} & Adverbial & 6 & 6 & 11 & 25 & 7 & 11 & \multicolumn{2}{|l|}{66} & 4.7 \\
\hline & & & & Preposition & 21 & 10 & 16 & 40 & 14 & 22 & \multicolumn{2}{|c|}{123} & 8.8 \\
\hline & & & & Pronoun & 7 & 1 & 2 & 1 & 3 & 2 & 16 & & 1.1 \\
\hline & & \multirow{3}{*}{\multicolumn{2}{|c|}{ Complement }} & $\begin{array}{l}\text { Common } \\
\text { Pronoun }\end{array}$ & 17 & 14 & 14 & 14 & 10 & 13 & \multicolumn{2}{|c|}{82} & 5.9 \\
\hline & & & & Nominalisation & 0 & 0 & 0 & 3 & 0 & 1 & \multicolumn{2}{|l|}{4} & 0.3 \\
\hline & & & & Adjective & 3 & 0 & 15 & 2 & 1 & 0 & \multicolumn{2}{|c|}{21} & 1.5 \\
\hline & \multirow{5}{*}{ Unmarked } & \multicolumn{3}{|c|}{ NG in declarative } & 110 & 121 & 161 & 223 & 132 & 146 & \multicolumn{2}{|c|}{893} & 63.9 \\
\hline & & \multicolumn{3}{|c|}{ Predicator in Imperative } & 0 & 0 & 0 & 0 & 1 & 0 & \multicolumn{2}{|l|}{1} & 0.1 \\
\hline & & \multicolumn{3}{|c|}{ Wh-word in Wh-Question } & 1 & 6 & 9 & 3 & 0 & 3 & \multicolumn{2}{|c|}{22} & 1.6 \\
\hline & & \multicolumn{3}{|c|}{ Finite Verb in Yes/No Question } & 3 & 2 & 6 & 0 & 1 & 0 & \multicolumn{2}{|c|}{12} & 0.9 \\
\hline & & \multirow{2}{*}{\multicolumn{3}{|c|}{ Clause as Theme }} & 26 & 17 & 40 & 31 & 19 & 24 & \multicolumn{2}{|c|}{157} & 11.2 \\
\hline & Total & & & & 194 & 177 & 274 & 342 & 188 & 222 & \multicolumn{2}{|c|}{1397} & 100 \\
\hline \multirow[t]{6}{*}{ Multiple } & \multirow{3}{*}{\multicolumn{2}{|c|}{ Textual }} & \multicolumn{2}{|c|}{$\begin{array}{l}\text { Continuative+ } \\
\text { Ideational }\end{array}$} & 3 & 0 & 6 & 5 & 4 & 0 & 18 & \multicolumn{2}{|c|}{9.3} \\
\hline & & & \multicolumn{2}{|c|}{$\begin{array}{l}\text { Conjunction+ } \\
\text { Ideational }\end{array}$} & 10 & 0 & 16 & 9 & 5 & 0 & 40 & \multicolumn{2}{|c|}{20.7} \\
\hline & & & $\begin{array}{l}\text { Conju } \\
\text { Ideatic }\end{array}$ & $\begin{array}{ll}\text { ictive } & \text { Adjunct+ } \\
\text { nal } & \\
\end{array}$ & 12 & 8 & 34 & 16 & 9 & 2 & 81 & 42 & \\
\hline & Interpers & & $\begin{array}{l}\text { Modal } \\
\text { Ideatic }\end{array}$ & $\begin{array}{ll}\text { nal } & \text { adjunct+ } \\
\end{array}$ & 6 & 5 & 24 & 16 & 3 & 0 & 54 & 28 & \\
\hline & & & Vocati & ves+ Ideational & 0 & 0 & 0 & 0 & 0 & 0 & 0 & 0 & \\
\hline & Total & & & & 31 & 13 & 80 & 46 & 21 & 2 & 193 & 100 & \\
\hline
\end{tabular}




\section{Semantic and Ideological Implications of the Simple Themes as Used in the Editorials}

The unmarked Theme occurred more than its marked counterpart in the simple thematic structure across the editorials. It was observed that these print media were mostly interested in communicating concise ideas to the members of the public rather than fronting certain syntactic elements when such can be expressed in plain structures. However, in some few excerpts, the preference for marked Themes (initial adjunct, complements) was informed by certain ideological undercurrents.

In the category of marked adjuncts, preposition-headed adjuncts appeared the most. It was observed that this preponderance of usage was due to the fact that a lot of details could be clustered into its syntax (through the Prepend-Completive structure) more than the adverb-headed adjuncts and marked complements.

THM1: In a deadly attack on Ikorodu villages in Lagos, suspected militants killed between 20 and 50 people... In Arepo, Ibafo and Mowe, in Obafemi-Owode LGA of Ogun State, the activities of the militants have become a nightmare for residents...In Ibafo, daring and well-armed militants engaged police and Nigerian Army troops in a gun duel in broad daylight during the visit of Yetunde Onanuga, the deputy governor of the state, to assess the damage done to petroleum pipelines.

The Punch, Clearing Lagos, Ogun of Murderous Militants, 15.07.2016

THM2: In the same Kano, the following day, two separate attacks took place: in the first case, a girl of about 17 years detonated a bomb at an NNPC mega station; the bomber along with five people died while others were injured. In the second incident, about three hours later, a 19-year-old girl blew herself up at the Kano Trade Fair ground; she was the only casualty. On Wednesday, July 30, another female teenage bomber killed herself at the entrance of Kano State Polytechnic; two got killed and 21 civilians were injured.

Leadership, Cowardly Fighters and Female Suicide Bombers, 06.08.2014

THM3: Between the president's inauguration on May 29 and today, no fewer than 500 Nigerians have been killed, hundreds more injured and property worth millions of naira destroyed by the sect. The Sun, Checking Boko Haram's Renewed offensive, 20.07.2015 
In the excerpts above, the preposition-headed adjuncts were instrumental in creating a strong imagery in the minds of the readers. In a bid to make readers accede to an urgent termination of security threats in Nigeria, details (relating to specific location, period, reason or purpose etc.) about cases of insecurity were provided. As much as editorials are not supposed to report situations anew, the newspapers considered these details necessary to substantiate whatever claims they make if such would be taken seriously. The marked adjunct in THM1 and THM2 provided in-depth information on the various locations where militancy and bomb explosions were recorded respectively. The Punch, established in the south-western part of Nigeria and located in Lagos, exploited the preposition-headed adjunct to project a sense of credibility and detailed accurate information needed to support its claims on the spread of militancy in different parts of south-west, Nigeria. The choice of this thematic structure may have been influenced by the fact that militancy is largely ascribed to the south-southern part of the country. Thus, this structure was meant to perform the function of presenting this security as being capable of snowballing into greater threats to the entire country.

Leadership also employed the thematised preposition-headed adjunct, giving full details about the locations and times of several cases of detonations in different parts of Kano. The northern newspaper attempted to project an image of its conversance with the severity of Boko Haram cases in the northern Nigeria. These specifics were needed in order to dissuade readers from taking such incidents with levity and were implicitly meant to bring about two possible reactions (fear and a strong desire to end security problems in the different regions in Nigeria). In THM3, the thematised prepositionheaded adjunct was intended by The Sun to generate a worrisome feeling on the number of lives that were lost in less than two months (between May 29, 2017 and July 20, 2017) as a result of the thriving activities of Boko Haram insurgents. This was to emphasise the brutality of the sect in Nigeria and accentuate the need to terminate their operations. The thematised preposition-headed adjunct in THM4 authenticated the realities of various security challenges in Nigeria.

Some of the thematised preposition-headed adjuncts were made to function as evidentials as seen in the excerpts below.

THM4: In a statement by his Special Adviser on Media and Publicity, Femi Adesina, Buhari said: "But another serious form of insecurity has reared its head on the Niger-Delta. The objective is to colonise the country economically by sabotaging oil and gas installations.

The Guardian, Niger Delta Militants can't Colonise, 31.10.2016

THM5: In its November 2015 report, the Sydney, Australia-based Institute for Economics and Peace, which codifies the GTI, labelled 
herdsmen as the fourth deadliest terror organisation in the world after Boko Haram, the Islamic State in Syria and Iraq and al-Shabab. "There have been reports of a link between Boko Haram and Fulani militants, particularly in regard to smuggling and organised crime. The Punch, Treating Violent herdsmen as Terrorists, 06.05.2016

In these excerpts, the principal aim of the newspapers was to tactically argue for degree of reliability of the claims in the reports. In THM4, The Guardian, in an attempt to avoid the misrepresentations of the interest of the Niger Delta agitators, exploited the thematised preposition-headed adjunct to attribute the derisive objectives about the plights of the Niger-Delta militants to the statement made by President Buhari as reported by the Special Adviser on Media and Publicity. The source of the information was fronted because it made a clear distinction of the "Sayer" and also provided a sort of innocence for the newspaper should there be any misrepresentation. The thematic option ideologically revealed that The Guardian does not subscribe to the activities of the Niger Delta agitators and that Buhari's statement reverberated with its attitudes.

In THM5, The Punch attributed the labelling of herdsmen as 'the fourth deadliest terror organisation in the world' to a 'Sayer' - the November 2015 report of the Sydney, Australia-based Institute for Economics and Peace. Although the ascriptions seemed to serve as a supporting statement for the newspaper's negative disposition towards the herders, yet the thematised element helped them to tactically claim innocence of being part of that ascription.

There were some other instances of the thematised preposition-headed adjuncts that simply were used by the newspapers to inject their prejudices towards certain security problems and personnel as seen in the excerpts below.

THM6: In a country where human life is valued, the effects of this gory incident would have attracted national attention.

Leadership, Killing in Defence of Cattle, Crops, 29.01.2014

THM7: In developed parts of the world, anti-terrorism units are elite military outfits that have become a nemesis to terrorists.

The Punch, Imperative of an Anti-Terrorism Taskforce, 30.08.2014

THM8: With an integrated militia within the Nigerian army, we are of the view that victory against the insurgents may yet be swifter than expected.

Leadership, The Rise of Vigilantes, 26.11.2014 
In THM6, Leadership used the thematised adjunct to project an insensitive image of the Nigerian government towards the life of its citizenry and its interest in the safety of cows. As at the time the editorial was written, cattle herders were posing a great challenge to the peace of the nation and so the newspaper ideologically draw attention to the perceived worthlessness placed on the lives of Nigerians. The thematic choice was intended to challenge the government to do more about the herdsmen killings.

Also, in THM7, The Punch thematised "in the developed part of the world" to project lack of confidence and inefficiency in the Nigerian anti-terrorism force. The thematic structure made an implied comparison between the Nigerian anti-terrorism force and those of the developed countries. The overriding intention was to depict the Nigerian anti-terrorism force as inexperienced and unskilled to handle the insurgents and propel them to either get trained or solicit foreign aid in order to bring the Boko Haram insurgents to book.

In THM8, the newspaper expressed its strong interest in an integrated militia within the Nigerian army in order to yield victory over the Boko Haram sect. This thematic choice may have been informed by the fact that the northern region suffers attacks the most from this sect and being a northern newspaper, it seemed to know where the shoe pinches the most.

In all the extracts above, the thematised preposition-headed adjuncts were used as linguistic tools of persuasion, aimed at feeding readers with necessary details, evidences and projecting prejudices necessary to make readers seek for the immediate solutions to security issues in Nigeria. From the very first clausal item, readers' interpretations are framed within the newspapers' perspectives to the issues being discussed.

Unlike the preposition-headed adjuncts, adverb-headed adjuncts appeared minimally in all the editorials. Most of the roles assigned to this kind of thematised adjunct were used to lead readers into interpreting certain propositions through specific temporal prisms.

THM9: Already, the United States government has, as part of efforts to contain the insurgency, declared Boko Haram as a terrorist group with a bounty on the head of its leader.

Leadership, The North as War Theatre? 24.02.2014

THM10: Many times, the attackers massacre the farmers at will, with no hope at all of help from security operatives.

The Sun, Stop the Killings Now, 28.04.2016

THM11: Barely a week ago, in Adamawa and southern part of Kaduna, some villages came under brutal attacks from the herdsmen 
in ways that left their victims in horror and the whole of Nigeria in shock...Recently, a traditional ruler, Lazarus Agai, the Saf Ron Kurele, in Bokkos town in Plateau State was killed while visiting his farm, by the same herdsmen.

The Guardian, The Menace of Herdsmen, 15.08.2016

In the examples above, the adverbial phrases of time in the thematic positions were immediately followed by parts of the clause that bear information on the occurrences of certain security challenges in the country. The overriding intention was to show the authenticity and frequency of various security menaces in Nigeria at different times. The thematised adverb-headed adjuncts seem to be pivotal in attracting the sympathy of the readers.

In THM9, Leadership thematised the finite adverbial clause of time 'already' in order to draw the attention of readers to the United States government's labelling of the Boko Haram sect. The thematised adverbial ideologically implied that Boko Haram's existence in Nigeria has lingered and their activities have been so grievous, especially in the northern Nigeria, that it has attracted global attention.

In THM10, the thematised adverbial phrase was used to signal the recurrent brutal attacks of the herdsmen on defenceless farmers in host communities. The Sun thematised "many times" to project the continuous ruthless activities of the herdsmen and get readers embittered against this group. The ideological implication of this thematic structure is heightened by the verbal group "massacre". The thematised adverbial also projected an unperturbed attitude of the government and security operatives about the situation despite the countless lives lost any time such clashes occur.

In THM11, the adverbial phrases were thematised to signal the activities of herdsmen. As at the various times when these editorials were written, there were rumours on the fact that the herdsmen have been overpowered in those states and that such menaces may soon become a thing of the past. The newspaper intended to project the existence of the groups and their spontaneous attacks at intervals. The thematised elements accentuated the subsequent loss of lives in the hands of this deadly group if their activities were allowed to fester.

Also, syntactic complements were also thematised to perform some ideological functions.

THM12: An attempt to colour electioneering in the country very dangerously was recently made by a group of former Niger Delta militants, who issues a threat to make the nation ungovernable should 
incumbent Goodluck Jonathan lose in the forthcoming presidential poll.

Leadership, The Threat by Ex-Militants, 05.02.2015

THM13: Over 50 people were reportedly killed and property worth millions of naira destroyed last week in a renewed attack on Tiv communities in Benue State by nomadic herdsmen.

Leadership, Killing in Defence of Cattle, Crops, 29.01.2014

THM14: Maiduguri was hit six times in October 2015 with 76 people killed.

Vanguard, End-game Strategies against Terror, 17.11.2015

In the above excerpts, the post-verbal elements were thematised through passivisation. THM12 is an excerpt on Niger Delta militancy in Nigeria and Leadership fronted the syntactic complement that bears the consequence of the activities of the former Niger Delta militants. The thematic structure projected Leadership's judgement and prejudice towards the activities of the militants. The editorial summed up their plights in a negative light and fronted it in order to create a bias in the minds of the readers against the group. In THM13, the aim of the newspaper was to front the affected - the killing of 'over 50 people' and destruction of 'property worth millions of naira', though not objectively, as the newspaper seemed to lack accuracy. This thematic structure was aimed at appealing to the emotional and psychological impulse of the readers. In this excerpt, Leadership though intended to project the irreparable havoc as well as the extent and worth of lives and properties of the affected first, it still employed a long passive (an explicit by-agentive adjunct) to reveal who the perpetrators of the acts are - the herdsmen.

In THM14, Maiduguri has been noted in the media as a trouble spot in Nigeria because Boko Haram's activities are universally accrued to it. The newspaper thematised the post-verbal element as a linguistic tool for getting the attention of readers to the thriving activities of Boko Haram in Nigeria.

Some instances of thematised complements were used to project uncomfortable viewpoints of the print media.

THM15: NDDC, a remarkable initiative, is known to have become a scheme for corruption and enrichment of a few.

The Guardian, On the Niger Delta and Amnesty Programme, 11.08.2014 
THM16: Standards have to be respected and established constitutional rights must be protected without making others feel any loss of their identities.

The Guardian, The Agitation for Biafra, 24 November, 2015

THM17: Both parties are advised to come to the negotiating table with the right tools and attitude.

The Sun, The FG/ Niger Delta Militants Dialogue, 04.09.2016

Olowe (1995: 242) posits in his research on thematisation in newspaper editorials that it is a 'veritable vehicle for accentuating some viewpoints and downplaying others'. The newspapers employed short passivised structures (the omission of the relegated byagentive adjuncts pointing to the Senser in THM15 and the Agents in THM16 and THM17). The choices of the short passives were an attempt by the newspaper to emphasise or front ideas (contained in the syntactic Goal) which seem to be ideologically uncomfortable. The Senser in THM15 may have been omitted because it relates to The Guardian's opinion of the Niger Delta Development Commission (NDDC). However, the choice of short passive construction afforded the newspaper an opportunity to implicitly position the Senser as 'all' or Nigerians' and to represent its judgement of the NDDC as public knowledge. The Guardian intended to appeal to the readers' emotion by fusing their ideas with that of the readers so that it counts as a unanimous idea.

In THM16 and THM17, the short passivised constructions gave the newspapers the opportunity to less assertively state ideas (contained in the thematised goals). Although the editorials considered these ideas valuable and results-yielding, they are careful to explicitly show the Agents, which obviously would have been "the news organisation", so that they do not damage their face before their readers.

THM18: So worrisome was the situation that three weeks after the abduction, Nigerians were at a loss about the state of the girls.

The Guardian, Chibok Girls: One Year After, 14.04.2015

THM19: More ominous is the arrest of Hadiza Musa, a 10-year-old girl, who was discovered to be wearing an explosive-fitted belt in Funtua, Katsina State, by security agents.

The Punch, Female Suicide Bombers on the Prowl, 05.08.2014

In the excerpts above, the syntactic complements were thematised through a device known as 'preposing' (Ward, Birner and Huddleston, 2002). In THM18, The Guardian thematised the post-verbal element "so worrisome" in order to induce worry over the safety of the abducted Chibok Girls amidst the callous Boko Haram sect, one year after their abduction. The marked complement thematised the fear of all Nigerians and was 
used to challenge the government to urgently do something about seeking the release of these girls. The reordered structure in THM19 enabled The Punch to foreground its attitude towards the incorporation of innocent children in the Boko Haram activities. "More ominous" was used by the newspaper to express worries over the dynamic strategies of the sect. The thematised complements were used to express shock over the age-group of children who were at that time being used to champion the course of this sect and to warn Nigerians not to be misled by the innocence of children and females. In essence, the marked complement was ideologically used to correct the mind-sets of readers and admonish all to be security conscious. The thematised complement could therefore be said to perform informative roles.

\subsection{Semantic and Ideological Implications of Multiple Themes as Used in the Editorials}

In the thematic position, the analysis also revealed that the textual Theme occurred more with the ideational Theme than did the interpersonal Theme. Conjunctive adjuncts and modal adjuncts (although appearing minimally) combined more with the ideational Theme than any other clausal element in the multiple thematic structures. A possible reason for the preponderance of the conjunctive adjunct + ideational Theme is the fact that it is used in achieving the kind of logicality needed to convince readers about taking drastic measures against security threats in Nigeria. If these editorials are to be taken seriously, grammatical items that signal logicality of points are essential, as these help the newspaper to achieve intended goals. Although the thematised conjunctive adjuncts had their meanings dependent on previous clauses, they were implicatively employed to perform certain roles in the clauses where they occur.

In the excerpts generally, most of the occurrences of the thematised conjunctive adjuncts were used as adversatives, emphases, correctives, causals, temporals, conditionals etc. and were immediately followed by ideational Themes in order to substantiate the claims of the newspapers on certain security issues as seen in the examples below.

THM20: The efforts of this group of people are highly commendable. The fact that they dare confront the enemy armed with bows and arrows, spears, clubs and dane guns, at great risk to their lives, is an indication of their bravery and desperation to resist the invaders and liberate their homeland. However, there are several unforeseen dangers and disadvantages that must not be overlooked. First, because they are poorly armed and ill trained they might easily be killed in battles with insurgents. Secondly, since they are not trained and have not taken the oath that every military man 
takes, they can easily switch loyalties. Thirdly, and perhaps the most likely danger of all, is that after Boko Haram is finally defeated...

Leadership, The Rise of Vigilantes, 26.11.2014

THM21: Indeed a sizeable part of the area has for years remained a killing field where hundreds of lives have been wasted, no thanks to the frequent clashes between the local farmers and nomadic Fulani herdsmen. In fact, no week passes without media reports of fresh attacks...For instance, between May and July this year, no fewer than 140 persons were reported killed when some suspected Herdsmen attacked some communities in Benue state.

Vanguard, Halt the Middle Belt Killings Now, 29.07.2015

THM22: The failure to prosecute those responsible for such killings is prima facie evidence in the international community that the victims can no longer count on Nigeria's judicial system to protect them, and would therefore need concerted international protection. In other words, the mindless killings qualify to attract international intervention, including investigations by the International Criminal Court (ICC).

The Sun, Time to Build Cattle Ranches, 15.10.2015

THM23: Militants moonlighting as robbers and kidnappers, have terrorised several Lagos and Ogun communities for a long time... they have fanned out to Lagos and Ogun. Though the state authorities noticed the pattern, they did nothing concrete to quickly curb the militancy. As a result, about 100 gunmen suspected to be militants confidently laid siege to Fatoki community in Igando, Lagos State, last week, in a three-day rampage.

The Punch, Clearing Lagos, Ogun of Murderous Militants, 15.07.2016

In THM20, the newspaper presented the incorporation of the local vigilantes in the collective fight against Boko Haram in the positive light and even eulogised the group for its courageousness in daring to fight the dreaded Boko Haram insurgents with inferior weapons. The thematised conjunctive adjunct 'However' was used to project Leadership's fears and worries and thus negative disposition to the involvement of the crude local vigilantes in the fight against Boko Haram. The conjunctive adjuncts signalling temporals (first, secondly, thirdly) provided an opportunity for the newspaper to elucidate on their fears while trying to ultimately dissuade the military forces and government from engaging in an act which may end up in future regrets. 
In THM21, the thematised conjunctive adjunct performed two functions: emphasis and appositive. In the first instance, Vanguard aimed at emphasising the weekly attacks and killings by nomadic herdsmen in the Middle Belt. Ideologically, the thematic choice was used to heighten the reality and thriving nature of herdsmen attacks in the Middle Belt. In the second instance, the conjunctive adjunct was used to further amplify Vanguard's points by exemplifying and giving records of the number of lives lost within two months (May-July) in 2015. Both lexico-grammatical choices were persuasively used to make Nigerians yearn for solutions to the killings, especially in that region.

In THM22, the conjunctive adjunct was employed to function as corrective, thus extending the opinion of The Sun on the cases of incessant killings by the herdsmen. The thematic structure was aimed at positioning herdsmen' activities as an issue worthy of international recognition and attention, and as such should not be treated as mere local or national affairs. The print media proposed that cases of herdsmen attacks deserve the kind of global attention paid to Boko Haram insurgency.

In THM 23, the thematised conjunctive adjunct accentuated a causal effect of the activities of the Niger Delta militants in Lagos. The Punch aimed to point the attention of readers to how the negligence of the state authorities has fanned the activities of Niger Delta militants to other parts of the country.

The modal + ideational thematic structure also had a high occurrence next to conjunctive+ ideational thematic structure. The choices of modal adjunct + ideational thematic structure were those which mostly reflected an air of desirability, opinion, probability, presumption and obviousness as seen in the examples below.

THM24: The region yearns for true development - beyond rhetoric and tokenism. Regrettably, institutions genuinely created to bring development to the region have merely compounded the problems and enriched only appointees or community or group leaders.

Guardian, On the Niger Delta and Amnesty Programme, 11.08.2014

THM25: Undoubtedly, the recent abduction of elder statesman, Olu Falae, by men suspected to be Herdsmen has once again highlighted the grave security threat posed by kidnapping to lives in Nigerians.

The Punch, Kidnapping: Need for Fresh Approach, 02.10.2015

THM26: Without doubt, such effort at community-level selfdefence would raise awareness at the grassroots that the continuous peace and safety of the community is the responsibility of everyone 
in the community, which in turn would heighten the awareness and civic duty of fishing out antisocial elements in the community and bringing them to the notice of the relevant authorities for appropriate action. Surely all of which in the end would expedite the process of finding a lasting solution to the nightmare of the insurgency that prevails among citizens now.

Daily Trust, the Kala/Balge Pushbacks against Insurgents, 26.05.2014

In THM24, The Guardian used "regrettably' to express disappointments over the activities of the institutions that were meant to oversee the needs of the Niger Delta people and how their dealings have rather heightened crises in this trouble spot.

In THM25 and THM26, the modal adjuncts were employed to express obviousness. The newspapers employed the thematised modal adjuncts 'obviously', 'undoubtedly' and 'without doubt' to accentuate the certainty of their claims. In THM25, the need to show the reality of nomadic herdsmen attacks in Nigeria and how they operate informed the use of the modal adjunct 'undoubtedly'. In THM26, the modal adjunct 'without doubt' was used to project Daily Trust's support for self-defence by communities and encourage members of communities to take the safety of their lives and properties in their hands.

\section{Summary and Conclusion}

This study has attempted an analysis of thematic choices in editorials on terrorism in Nigeria and how such choices were used to frame the media's perspectives and drive readers' interpretations on certain segments of the editorials. In all the newspaper editorials, preposition-headed adjuncts occurred the most in the category of marked adjuncts and were used to supply details needed to support the claims of the activities of insurgents in certain regions as well as the realities of certain security challenges in different parts of the country. Marked adjuncts were also used to attribute certain claims to external sources other than the news organisations, inject prejudices and also mark the extent of commitment that the newspapers have in their propositions. The adverb-headed adjuncts were used to accentuate the exact periods/times when security problems occurred. Complements were thematised to project the sufferers/victims of violence, thus needed to achieve emotive effects on the audience. The multiple Themes were made to function as additives, adversatives, correctives, emphases and express the newspaper's stance towards security issues and security measures in the editorial. Through the thematic analysis, it was observed that all the newspapers expressed concern over the security issues raised in the editorials without biases. The newspapers employed thematic relations that explicitly projected its negative disposition to the violent activities of cattle herders, Boko Haram insurgents and Niger Delta militant in Nigeria. 


\section{References}

Ayoola, K. 2010. The presentation of ideological perspectives on Niger-Delta discourse in Nigerian Newspapers. Journal of the Nigeria English Studies Association (JNESA), 13(1), 17-32.

Bloor T., \& Bloor M. 1995. The fundamental analysis of English. London: Edward Arnold.

Chinwokwu, E. 2012. History and dynamics of terrorism in Nigeria: Socio-political dimension. International Journal of Innovative Research and Development, 1(11), 419-449.

Dankano, S. 2010. U.S listing of Nigeria as terror state: matters arising. http://thewillingnigeria.com/opinions/3467 Retrieved on 05/07/2018

Downing, A., \& Locke, P. 2006. English grammar - A university course. New York: Routledge.

Ekeanyanwu, N., \& Jokodola, O. 2009. Analysis of the content of Nigeria's newspaper editorials. Oko Journal of Communication and Information Science, 1(2), 73103.

Fries, P. 1995. Personal view of theme: Thematic development in English text. In Ghadessy, M. (ed.), Register Analysis, 335-359. London: Pinter.

Halliday, M., \& Mathiessen, C. 2004. An introduction to functional grammar. London: Hodder Education.

Halliday, M., \& Mathiessen, C. 2014. Halliday's introduction to functional grammar. New York: Routledge.

Huddleston, R. 1988. English grammar - An outline. Cambridge: Cambridge University Press.

Igwebuike, E., \& Taiwo, R. 2015. Representation of Bakassi Peninsula conflict in Nigeria and Cameroon print media: A critical discourse approach. Linguistik online 73, 4(15), 29-45.

Lafrue, G. \& Dugan, L. 2007. Introducing the global terrorism database. Terrorism and political violence, 19: 181-204 DOI: 10.1080/09546550701246817 Leadership Newspaper, Nigeria.

Ojeme, V. 2011. Nigeria still on European terror watch list. http://www.vangaurdngr.com/2011/08/nigeriastilloneuropeanwatch list/

Osisanwo, A. 2016. Discursive representation of Boko Haram terrorism in selected Nigerian newspapers. Discourse and Communication, 1-22.

Osisanwo, W. 2001. Textuality and Nigerian newspaper editorials: The example of The Guardian. Ife Studies in English Language, 5, 1-9.

Owolabi, D. 2016. Perception of English usage in expressing validity on products and services. Papers in English and Linguistics (PEL), 17, 241-254.

Taiwo, R. 2001. Thematic structure in English-medium Nigerian newspaper Reports. Ife Studies in English Language, 5(1), 58-67. 
Daily Trust Newspaper, Nigeria.

Leadership Newspaper, Nigeria.

The Guardian Newspaper, Nigeria.

The Punch Newspaper, Nigeria.

The Sun Newspaper, Nigeria.

Vanguard Newspaper, Nigeria.

\section{A LIST OF ABBREVIATED WORDS}

LEs - Leadership Editorials

VEs - Vanguard Editorials

GEs - The Guardian Editorials

PEs - The Punch Editorials

SEs - The Sun Editorials

DTEs - Daily Trust Editorials

THM - Theme

NG - Nominal Group 